\title{
Chronic graft-versus-host disease - the role of dermatological treatment
}

\section{Przewlekła choroba przeszczep przeciwko gospodarzowi - znaczenie leczenia dermatologicznego}

Magdalena Żychowska, Joanna Gruber-Kopczyńska, Małgorzata Tupikowska-Marzec, Joanna Maj

Department of Dermatology, Venereology and Allergology, Wroclaw Medical University, Wroclaw, Poland

Klinika Dermatologii, Wenerologii i Alergologii, Uniwersytet Medyczny im. Piastów Śląskich we Wrocławiu, Polska

Dermatol Rev/Przegl Dermatol 2017, 104, 1 12-121

DOI: https://doi.org/l0.5।|4/dr.2017.67385

\author{
CORRESPONDING AUTHOR/ \\ ADRES DO KORESPONDENCJI: \\ lek. Magdalena Żychowska \\ Klinika Dermatologii, \\ Wenerologii i Alergologii \\ Uniwersytet Medyczny \\ im. Piastów Śląskich \\ we Wrocławiu \\ ul. Chałubińskiego 1 \\ 50-368 Wrocław, Polska \\ tel.: +48 669422237 \\ e-mail: \\ magda.zychowska@gmail.com
}

\begin{abstract}
Introduction. The number of allogeneic haematopoietic stem cell transplantations is increasing year by year. The most common long-term complication is chronic graft-versus-host disease, with skin involvement noted in over $90 \%$ of cases.

Objective. To present and discuss skin lesions occurring in chronic graft-versus-host disease with a particular focus on available dermatological treatment modalities.

Case report. A 45-year-old male patient, who received allogeneic haematopoietic stem cell transplantations in December 2012, presented for the treatment of skin lesions secondary to chronic graft-versus-host disease. Clinical examination revealed hyperpigmented lichenoid eruption on the trunk; irregular patches of non-scarring alopecia; poikiloderma on the face and upper limbs; and sclerodermatous lesions on the hands with diffuse epidermal exfoliation on the palms and soles. Histopathological examination confirmed the diagnosis of chronic graft-versus-host disease. Treatment consisting of phototherapy and intensive topical treatment was introduced.

Conclusions. Skin lesions secondary to chronic graft-versus-host disease may impair the daily functioning of post-transplant patients. Comprehensive therapeutic management should be based on the cooperation between haematologists and dermatologists.
\end{abstract}

\section{STRESZCZENIE}

Wprowadzenie. Z każdym rokiem wzrasta liczba wykonywanych alogenicznych przeszczepów komórek macierzystych. Najczęstszym odległym powikłaniem tych zabiegów jest przewlekła choroba przeszczep przeciwko gospodarzowi, w przebiegu której u 90\% pacjentów dochodzi do zajęcia skóry.

Cel pracy. Przedstawienie i omówienie zmian skórnych występujących w przebiegu przewlekłej choroby przeszczep przeciwko gospodarzowi ze szczególnym zwróceniem uwagi na możliwości leczenia dermatologicznego.

Opis przypadku. Przedstawiamy przypadek 45-letniego mężczyzny po przeszczepie szpiku przeprowadzonym w grudniu 2012 r., który zo- 
stał przyjęty w celu leczenia zmian skórnych w przebiegu przewlekłej choroby przeszczep przeciwko gospodarzowi. W badaniu klinicznym stwierdzono: przebarwioną liszajopodobną osutkę na tułowiu, nieregularne ogniska przerzedzenia włosów, zmiany poikilodermiczne na twarzy i kończynach górnych oraz stwardnienie skóry rąk z grubopłatowym złuszczaniem naskórka na dłoniach i podeszwach. Badanie histologiczne potwierdziło rozpoznanie przewlekłej choroby przeszczep przeciwko gospodarzowi. W leczeniu zastosowano fototerapię oraz intensywne leczenie miejscowe.

Wnioski. Zmiany skórne w przebiegu przewlekłej choroby przeszczep przeciwko gospodarzowi mogą upośledzać funkcjonowanie pacjentów po przeszczepach. Kompleksowa opieka powinna się opierać na współpracy pomiędzy hematologami i dermatologami.

Key words: phototherapy, PUVA, chronic graft-versus-host disease, extracorporeal photopheresis.

Słowa kluczowe: fototerapia, PUVA, przewlekła choroba przeszczep przeciwko gospodarzowi, fotofereza pozaustrojowa.

\section{INTRODUCTION}

The number of allogeneic haematopoietic stem cell transplantations (allo-HSCT) is growing year by year. Thanks to ongoing improvements in haematological care, the survival period of allo-HSCT recipients is increasing as well. Graft-versus-host disease (GVHD) is the most common complication of allo-HSCT. It affects $40-60 \%$ of recipients and is responsible for $15 \%$ of deaths [1]. GVHD occurs less frequently after solid organ transplantations or blood transfusions. The disease develops when the immune cells of an immunocompetent donor begin to identify and attack the tissues of a recipient. GVHD is more common when the donor and recipient are unrelated, and when the donor is a woman (particularly multiparous). The greater the number of incompatible alleles in the histocompatibility complex between the donor and the recipient, the higher the risk of the disease [2].

Four forms of GVHD are officially recognized according to the National Institutes of Health [3]:

- acute graft-versus-host disease (aGVHD) - occurring in the first 100 days after transplant,

- late-onset aGVHD - involving symptoms typical of the acute form but developing more than 100 days after transplant,

- chronic graft-versus-host disease (cGVHD) - occurring more than 100 days after transplant,

- overlap syndrome - exhibiting features of both aGVHD and cGVHD.

Considering that the skin is the most commonly involved organ in cGVHD, dermatologists should be familiar with the clinical symptoms of the disease and

\section{WPROWADZENIE}

Z każdym rokiem wzrasta liczba wykonywanych alogenicznych przeszczepów komórek macierzystych (allo-HSCT). Dzięki coraz lepszej opiece hematologicznej wydłuża się czas przeżycia biorców. Choroba przeszczep przeciw gospodarzowi (GVHD) jest najczęstszym powikłaniem allo-HSCT. Występuje u 40-60\% biorców i odpowiada za 15\% zgonów [1]. Rzadziej GVHD pojawia się po przeszczepach narządów litych lub przetoczeniach. Do rozwoju choroby dochodzi, gdy komórki immunologiczne immunokompetentnego dawcy zaczynają rozpoznawać i atakować tkanki biorcy. Do wystąpienia GVHD dochodzi częściej, gdy dawca i biorca nie są spokrewnieni oraz gdy dawcą jest kobieta (zwłaszcza wieloródka). Im więcej niezgodnych alleli w układzie zgodności tkankowej pomiędzy dawcą a biorcą, tym większe jest ryzyko rozwoju choroby [2].

Według klasyfikacji National Institutes of Health wyróżnia się cztery odmiany GVHD [3]:

- ostrą (aGVHD) - rozwijającą się w ciągu 100 dni po przeszczepie,

- ostrą o późnym początku (late-onset aGVHD) - przebiegającą z objawami typowymi dla postaci ostrej, ale występującą po 100 dniach od przeszczepu,

- przewlekłą (cGVHD) - rozwijającą się po 100 dniach od przeszczepu,

- zespół nakładania - o cechach zarówno aGVHD, jak i cGVHD.

Ze względu na fakt, że skóra jest narządem najczęściej zajętym w przebiegu cGVHD, dermatolodzy powinni znać objawy kliniczne choroby i możliwości 
available therapeutic modalities. Dermatological maintenance therapy plays an important role in the care of post-transplant patients, and may contribute to an improvement in their quality of life and daily functioning.

\section{OBJECTIVE}

To present the case of a patient with extensive multiform skin lesions secondary to cGVHD and discuss available dermatological treatment modalities.

\section{CASE REPORT}

A 45-year-old male patient, who underwent allo-HSCT for B-cell acute lymphoblastic leukaemia in December 2012, was admitted to the Department of Dermatology for the treatment of skin lesions secondary to cGVHD. The first skin lesions presenting as hyperpigmented spots and papules, mainly on the trunk, appeared in January 2013. The patient was diagnosed with the acute form of GVHD. The initial treatment of aGVHD was based on ciclosporin A at $800 \mathrm{mg} /$ day (ca. $12.5 \mathrm{mg} / \mathrm{kg}$ bw), however the drug was discontinued due to impaired kidney function. Then, extracorporeal photopheresis (ECP) was performed, producing a slight improvement in skin condition. The patient presented to the Department due to increased severity of sclerodermatous lesions on the hands and hyperkeratotic lesions on the palms and soles, accompanied by painful hand and foot swelling which limited the patient's mobility. Clinical examination revealed multiform skin lesions including hyperpigmented lichenoid eruption on the trunk, with the tendency of the lesions to coalesce in the interscapular region (Fig. 1); small flaky silvery white scales on the scalp accompanied by multiple irregular patches of non-scarring alopecia; multiple variously shaped focal poikilodermal changes, primarily on the face and upper limbs on the extensor side (Fig. 2); sclerodermatous lesions on the hands with diffuse epidermal exfoliation on the palms and soles (Fig. 3); loss of nail plates and whitening of the oral mucosa. The patient was under constant supervision of a haematology outpatient clinic, and laboratory tests performed on admission showed slight abnormalities in peripheral blood $\mathrm{CBC}$, persisting at a constant level after allo-HSCT (WBC - 12.86 thousand $/ \mu 1, \mathrm{RBC}-3.35$ million/ $\mu \mathrm{l})$. On histological examination, the epidermis was found to be thinned, with a polished appearance, swollen, affected by hyperkeratosis and vacuolar degeneration within the basal and spinous layers. The upper layers of the dermis revealed intra- and extracellular accumulation of pigment (incontinentia pigmenti) as well as sparse inflammatory infiltrations with a scattered distribu- terapeutyczne. Podtrzymujące leczenie dermatologiczne odgrywa ważną rolę w opiece nad pacjentami po przeszczepach i może się przyczynić do poprawy jakości ich życia i codziennego funkcjonowania.

\section{CEL PRACY}

Przedstawienie pacjenta $\mathrm{z}$ rozległymi, wielopostaciowymi zmianami skórnymi w przebiegu cGVHD oraz omówienie możliwości leczenia dermatologicznego.

\section{OPIS PRZYPADKU}

Mężczyzna 45-letni, u którego przeprowadzono allo-HSCT w grudniu 2012 r. z powodu ostrej białaczki limfoblastycznej B-komórkowej, został przyjęty do Kliniki Dermatologii w celu leczenia zmian skórnych w przebiegu cGVHD. Pierwsze zmiany skórne w postaci przebarwionych plam i grudek, głównie na tułowiu, zaczęły się pojawiać w styczniu 2013 r. U pacjenta rozpoznano wówczas ostrą postać GVHD. Z powodu aGVHD pacjent początkowo był leczony cyklosporyną A w dawce 800 mg/dobę (ok. 12,5 mg/ kg m.c.), którą odstawiono ze względu na pogorszenie czynności nerek. Następnie wykonywano zabiegi fotoferezy pozaustrojowej (ECP) i uzyskano nieznaczną poprawę stanu skóry. Powodem zgłoszenia się pacjenta do Kliniki było nasilenie stwardnień skóry rąk oraz zmian hiperkeratotycznych na dłoniach i podeszwach, czemu towarzyszył bolesny obrzęk rąk i stóp, utrudniający poruszanie się. W badaniu klinicznym stwierdzono wielopostaciowe zmiany skórne: przebarwioną liszajopodobną osutkę na tułowiu z tendencją do zlewania się zmian w okolicy międzyłopatkowej (ryc. 1); drobnopłatową, srebrzystobiałą łuskę na skórze owłosionej głowy i liczne, nieregularne ogniska przerzedzenia włosów; liczne różnokształtne ogniska poikilodermiczne, głównie na twarzy i kończynach górnych po stronie prostowników (ryc. 2); stwardnienie skóry rąk z grubopłatowym złuszczaniem naskórka na dłoniach i podeszwach (ryc. 3); spełzanie płytek paznokciowych oraz zmleczenia na błonach śluzowych jamy ustnej. Pacjent był pod stałą opieką poradni hematologicznej, a w badaniach laboratoryjnych wykonanych przy przyjęciu stwierdzono nieznaczne odchylenia w morfologii krwi obwodowej, utrzymujące się na stałym poziomie od czasu allo-HSCT (WBC - 12,86 tys./ $\mu \mathrm{l}$, RBC - 3,35 mln/ $\mu \mathrm{l}$ ). $\mathrm{W}$ badaniu histologicznym skóry obserwowano ścieńczały naskórek, wygładzony, obrzęknięty, z hiperkeratozą oraz zwyrodnienie wodniczkowe w strefie warstwy podstawnej i kolczystej. W górnych partiach skóry właściwej śród- i pozakomórkowo nagromadzony był barwnik (incontinentia pigmenti) oraz obecne były skąpe nacieki zapalne, rozproszone, miejscami 


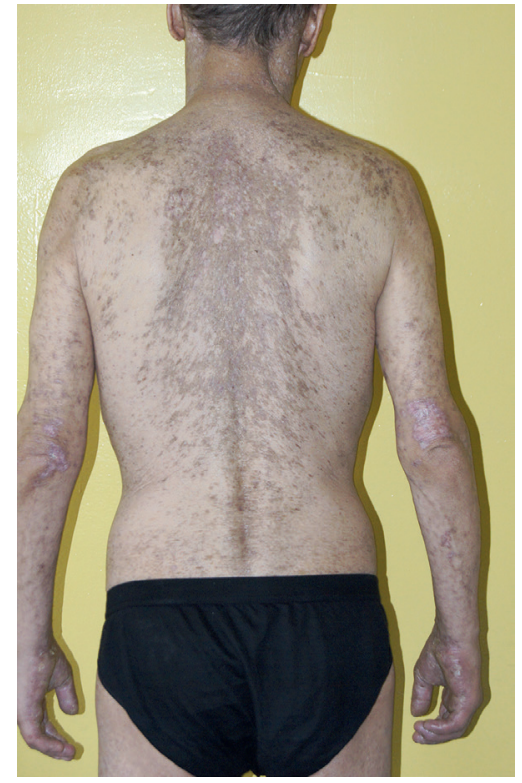

Figure I. Hyperpigmented lichenoid eruption on the trunk with a tendency to coalesce in the interscapular region. Poikilodermatous lesions visible on the extensor surfaces of the upper limbs

Rycina I. Przebarwiona osutka liszajopodobna na tułowiu z tendencja do zlewania się w okolicy międzyłopatkowej. Na powierzchniach wyprostnych kończyn widoczne zmiany poikilodermiczne

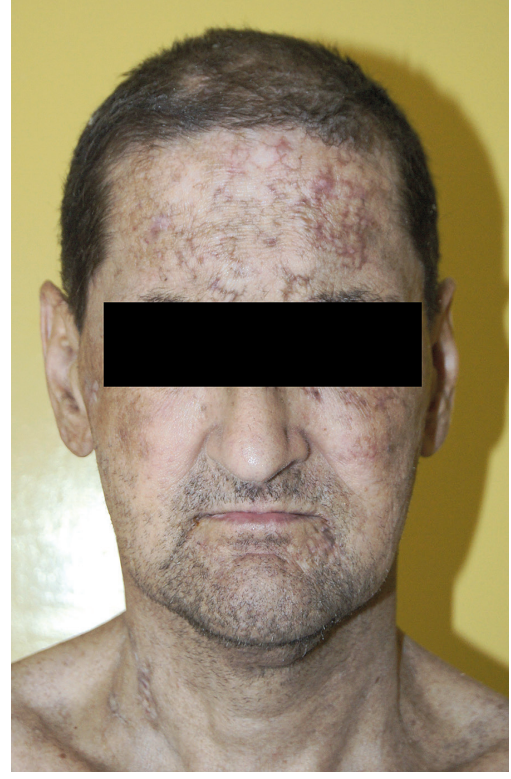

Figure 2. Poikilodermatous lesions on the face (hyperpigmentation, hypopigmentation, atrophy and telangiectasias)

Rycina 2. Zmiany poikilodermiczne na twarzy (przebarwienia i odbarwienia, zmiany zanikowe i teleangiektazje)

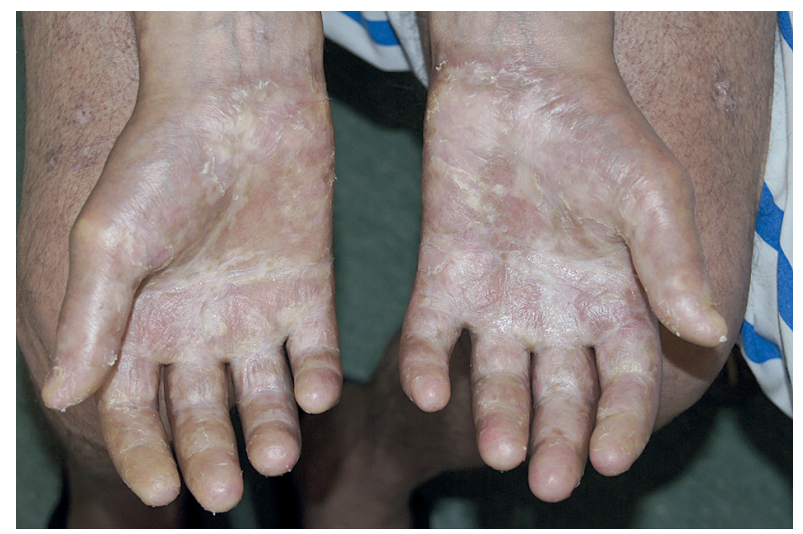

Figure 3. Sclerodermatous lesions on the hands with contractures of the fingers and epidermal exfoliation on the palms

Rycina 3. Stwardnienie skóry rąk z towarzyszq̨cymi przykurczami palców oraz pogrubienie i złuszczanie naskórka na dłoniach

tion, locally exhibiting mild epidermotropism. The collagen fibres were shown to be thinned, fragmented, with a blurred structure. The findings were consistent with the clinically observed cGVHD.

The patient received PUVA phototherapy ( 2 treatments per week, 20 treatments overall, total dose $\left.26 \mathrm{~J} / \mathrm{cm}^{2}\right)$, Psorilux therapy to the hands and feet (wavelength 281-315 nm, 3 treatments per week, 30 treatments overall) and intensive topical therapy wykazujące słaby epidermotropizm. Włókna kolagenowe były ścieńczałe, pofragmentowane, o zatartej strukturze. Obraz ten potwierdził obserwowaną klinicznie cGVHD.

W leczeniu zastosowano fototerapię PUVA (2 naświetlania w tygodniu, łącznie 20 naświetlań, sumaryczna dawka $26 \mathrm{~J} / \mathrm{cm}^{2}$ ), lampy Psorilux na dłonie i stopy (długość fali 281-315 nm, 3 naświetlania w tygodniu, łącznie 30 naświetlań) oraz intensywne 
(keratolytic and steroid ointments, emollients). The therapy caused an improvement in the patient's skin condition, decreased the painful sensation within the hands and feet, and increased the patient's mobility.

\section{DISCUSSION}

The chronic form of GVHD develops in 60-80\% of post-transplant patients, and skin involvement is observed in over $90 \%$ of all cases [3]. In addition to being a potentially significant cosmetic problem and limiting the daily functioning of patients, skin lesions secondary to GVHD may be a life-threatening condition. Two main dermatologic manifestations of cGVHD are typically distinguished: lichenoid (developing at the earlier stage of the disease) and sclerotic (associated with a worse prognosis and occurring in the later period after transplantation) [4]. Only in a proportion of patients lichenoid lesions evolve into sclerotic lesions. Also, the sclerotic dermatologic manifestation of cGVHD is preceded by the lichenoid manifestation in just $40 \%$ of cases [5]. The histopathological features of the lichenoid form are similar to classic lichen planus, with hyperkeratosis, hypergranulosis, acanthosis, basal layer vacuolization and a band-like lymphocytic infiltration "adhering" to the basement membrane. In the sclerotic form, the morphology of skin lesions may be consistent with lichen sclerosus - presenting as epidermal atrophy, and oedema and homogenization of collagen seen on histological examination - or localized scleroderma (morphea) [6]. Other possible manifestations of cGVHD include vesicular skin eruptions, ulcers, poikilodermatous lesions, granuloma pyogenicum-like lesions, anetoderma and pigmentation disorders [6]. Severe sclerodermatous lesions may lead to joint contractures and significantly reduce patient mobility.

cGVHD also frequently affects the mucosa of the oral cavity, genitals and conjunctiva; and inflammatory lesions may heal leaving behind adhesions. In view of the above, allo-HSCT recipients should be not only under regular dermatological supervision but also under ophthalmological and gynaecological care.

Basic dermatological recommendations applicable to transplant recipients include:

- avoidance of sun exposure, particularly between 10 am and $4 \mathrm{pm}$; and regular use of photoprotective methods (protective clothing; application of SPF30 (or higher) sunscreen prior to sun exposure) due to the risk of GVHD exacerbation, development of skin cancer, post-inflammatory hyperpigmentation and phototoxic reactions (in patients treated with azithromycin, fluoroquinolones, hydrochlorothiazide, trimethoprim with sulphamethoxazole, voriconazole) $[7,8]$, leczenie miejscowe (maści keratolityczne, glikokortykosteroidowe, emolienty). Dzięki zastosowanej terapii uzyskano poprawę stanu miejscowego, zmniejszenie bolesności rąk i stóp i ułatwienie poruszania się.

\section{OMÓWIENIE}

Przewlekła postać GVHD występuje u 60-80\% pacjentów po przeszczepie, a skóra zajęta jest w ponad 90\% przypadków [3]. Zmiany skórne mogą nie tylko być dla pacjentów znacznym problemem kosmetycznym i ograniczać ich codzienne funkcjonowanie, lecz także zagrażać ich życiu. Tradycyjnie wyróżnia się dwie główne odmiany cGVHD - liszajopodobną (rozwijającą się we wcześniejszej fazie choroby) i twardzinopodobną (związaną z gorszym rokowaniem i występującą w późniejszym okresie po przeszczepie) [4]. Tylko u części pacjentów postać liszajopodobna przechodzi w twardzinopodobną. Z kolei postać twardzinopodobna jest poprzedzona postacią liszajopodobną jedynie w 40\% przypadków [5]. Obraz histopatologiczny postaci liszajopodobnej przypomina klasycznego liszaja płaskiego - obecna jest hiperkeratoza, hipergranuloza, akantoza, wakuolizacja warstwy podstawnej oraz pasmowaty naciek limfocytarny "przylegający” do błony podstawnej. W postaci twardzinopodobnej morfologia zmian może odpowiadać liszajowi twardzinowemu, z atrofią naskórka oraz obrzękiem i homogenizacją kolagenu w obrazie histologicznym, lub twardzinie ograniczonej (morphea) [6]. W przebiegu cGVHD mogą również występować: wykwity pęcherzowe, owrzodzenia, zmiany poikilodermiczne, zmiany typu ziarniniaków ropotwórczych, anetodermia oraz zaburzenia pigmentacji [6]. Konsekwencją nasilonych stwardnień skóry może być powstanie przykurczów w stawach oraz znaczne ograniczenie zdolności poruszania się.

W przebiegu cGVHD często dochodzi również do zajęcia błon śluzowych jamy ustnej, narządów płciowych i spojówek, a zmiany zapalne mogą się goić z pozostawieniem zrostów. Stąd biorcy allo-HSCT powinni być nie tylko pod stałą opieką dermatologiczną, lecz także okulistyczną i ginekologiczną.

Podstawowe zalecenia dermatologiczne dla biorców przeszczepów obejmują:

- unikanie ekspozycji na światło słoneczne, szczególnie między godziną 10 a 16, oraz regularne stosowanie fotoprotekcji (odzież ochronna, kremy z filtrem SPF 30 lub wyższym) ze względu na ryzyko zaostrzenia GVHD, rozwoju nowotworów skóry, przebarwień pozapalnych oraz reakcji fototoksycznych (dotyczy pacjentów przyjmujących m.in. azytromycynę, fluorochinolony, hydrochlorotiazyd, trimetoprim z sulfametoksazolem, worikonazol) [7, 8], - regularną pielęgnację skóry za pomocą emolientów lub preparatów z 3-10\% mocznikiem, co pomaga 
- regular skin care with emollients or formulations containing 3-10\% urea, which helps to normalize the skin's moisture content, restore the lipid barrier and reduce pruritus,

- annual dermatological examinations for cancers of the skin and mucous membranes due to an elevated risk of actinic keratosis, basal cell carcinoma and squamous cell carcinoma; in patients with a history of skin cancer the frequency of dermatological assessments during immunosuppressive therapy should be increased, with examinations performed on a 6 monthly basis; after the completion of immunosuppressive therapy follow-up examinations may be performed once a year $[7,8]$,

- regular dermoscopic assessment due to an increased risk of melanoma in allo-HSCT recipients [7-9],

- earliest possible introduction of therapy in patients with sclerotic GVHD due to the risk of joint contractures and reduced mobility; treatment should be combined with regular physiotherapy.

Even though cGVHD is a systemic disease with complex pathophysiology, topical treatment plays an important role in the care provided to allo-HSCT recipients. In the mild form of the disease, confined to the skin, topical therapy may prove to be sufficient, and help to avoid systemic immunosuppression. In moderate and severe forms of cGVHD, topical treatment is an important adjunct to systemic therapy (most commonly used systemic drugs: glucocorticosteroids (GCs), ciclosporin A, tacrolimus, mycophenolate mofetil), improving its efficacy and thus making it possible to minimize the duration of immunosuppressive therapy and reduce its toxicity. Following the introduction of systemic treatment, many patients achieve a significant improvement or remission of skin changes in the majority of areas, with lesions remaining in isolated sites, e.g. on mucous membranes. In such cases, adjunctive topical treatment is particularly beneficial $[7,8]$.

Drugs used in topical skin treatment include GCs and calcineurin inhibitors (preferred option on the skin of the face and intertriginous areas, and in children) [7]. In mild forms of cGVHD, first-line treatment should be based on moderate- or high-potency GCs. However, possible complications of long-term therapy should be taken into consideration, including skin atrophy, secondary infections and the risk of absorption and systemic effects, especially in young children. A number of authors recommend the use of higher-potency GCs at the start of therapy in order to achieve a rapid improvement in skin condition, to be followed by a gradual introduction of lower-potency GCs or a decrease in the frequency of glucocorticosteroid use. The above regimen makes it possible to avoid the risk of tachyphylaxis $[7,8]$. przywrócić prawidłowe nawilżenie skóry, sprzyja odbudowie bariery lipidowej i zmniejsza świąd,

- wykonywanie raz w roku badania dermatologicznego w kierunku nowotworów skóry i błon śluzowych ze względu na zwiększone ryzyko rozwoju rogowacenia słonecznego, raka podstawnokomórkowego i kolczystokomórkowego; u pacjentów, u których w przeszłości zdiagnozowano raka skóry, należy zwiększyć częstość oceny dermatologicznej $\mathrm{w}$ trakcie leczenia immunosupresyjnego i przeprowadzać badanie raz na 6 miesięcy; po zakończeniu leczenia immunosupresyjnego badanie kontrolne może być wykonywane 1 raz w roku [7, 8],

- regularną ocenę dermoskopową ze względu na zwiększone ryzyko rozwoju czerniaka [7-9],

- jak najwcześniejsze rozpoczęcie terapii postaci twardzinopodobnej ze względu na ryzyko rozwoju przykurczów w stawach i ograniczenia ruchomości; leczenie powinno być połączone z regularną fizjoterapią.

Chociaż cGVHD jest chorobą systemową o złożonej patofizjologii, leczenie miejscowe odgrywa ważną rolę w opiece nad biorcami allo-HSCT. W łagodnej postaci choroby ograniczonej do skóry miejscowa terapia może okazać się wystarczająca i pomaga uniknąć ogólnoustrojowej immunosupresji. W postaciach cGVHD o nasileniu umiarkowanym i ciężkim leczenie miejscowe jest ważnym uzupełnieniem terapii systemowej (najczęściej w leczeniu ogólnym stosuje się glikokortykosteroidy (GKS), cyklosporynę A, takrolimus, mykofenolan mofetylu), gdyż zwiększa jej skuteczność i pozwala na szybsze odstawienie leczenia immunosupresyjnego i zmniejszenie jego toksyczności. U wielu pacjentów po włączeniu leczenia ogólnoustrojowego może nastąpić znaczna poprawa lub remisja zmian skórnych na większości obszarów, z pozostawieniem zmian w pojedynczych lokalizacjach, np. na błonach śluzowych. W takich przypadkach uzupełniające leczenie miejscowe ma szczególne znaczenie [7, 8].

W terapii miejscowej zmian skórnych stosuje się GKS oraz inhibitory kalcyneuryny (zalecane na twarzy, w okolicach wyprzeniowych oraz u dzieci) [7]. W łagodnych postaciach cGVHD leczeniem pierwszego rzutu powinny być GKS o umiarkowanej lub silnej mocy. Należy jednak pamiętać o powikłaniach długoterminowej terapii, takich jak zaniki skórne, wtórne infekcje, oraz ryzyku wchłaniania i działania ogólnoustrojowego, zwłaszcza u małych dzieci. Wielu autorów zaleca rozpoczęcie leczenia od GKS o większej mocy w celu uzyskania szybkiej poprawy stanu skóry, a następnie stopniowe wprowadzanie słabszych GKS lub zmniejszenie częstości ich stosowania. Pozwala to na uniknięcie zjawiska tachyfilaksji $[7,8]$.

Fototerapia odgrywa ważną rolę w leczeniu cGVHD, głównie odmiany twardzinopodobnej. Promieniowanie UV ma działanie antyproliferacyj- 
Phototherapy is a vital component of the treatment of cGVHD, mainly the sclerotic type. UV radiation induces antiproliferative and immunomodulatory effects. In addition, it has an impact on cytokine production, cell activation, antigen presentation and apoptosis of T-cells, among others [10]. Phototherapy has been shown to be an effective therapeutic tool both in the treatment of acute and chronic GVHD. The method is a particularly good alternative in patients with disseminated skin lesions, as systemic immunosuppression in this group would entail a high risk of infectious complications or other adverse reactions.

Therapeutic modalities used in the treatment of cGVHD patients include wide-band UVB (280-320 $\mathrm{nm})$, narrow-band UVB (311 nm), PUVA (8-methoxypsoralen taken orally prior to UVA irradiation 320-400 nm) and UVA1 (340-400 nm). When selecting a phototherapy technique, consideration should be given to the type of skin lesions, among other factors. In patients with superficial skin lesions, e.g. in the lichenoid form, it may be sufficient to administer UVB phototherapy which is absorbed in the epidermis and without penetrating into the deeper layers of the dermis. However, the sclerotic form requires UVA phototherapy which penetrates into the dermis $[7,8]$. It is also imperative to note that phototherapy increases the risk of skin cancer development in transplant recipients.

An important method of treating patients with cGVHD is ECP. ECP is a type of systemic phototherapy which is associated with a high level of patient safety. The procedure consists of three stages: 1 ) isolation of leukocytes from the patient, 2) photoactivation using a photosensitizer added directly to the leukocyte buffy coat, followed by leukocyte exposure to UVA radiation, and finally 3 ) reinfusion of leukocytes. The entire procedure takes approximately 3-4 hours. It is usually performed during 2 consecutive days and repeated every 2-4 weeks [11, 12]. ECP was first used in 1987 for the treatment of the erythrodermic form of primary cutaneous T-cell lymphomas [13]. Currently, the method is most commonly used in the therapy of cGVHD. The response rate in transplant recipients is about $63 \%$ [11]. The most frequent adverse effects of ECP include hypotension during the procedure, fever, erythema and nausea [14]. The mode of action of ECP in CGVHD has not been sufficiently elucidated. Its efficacy is believed to be due to the effect of the method on the Th1-to-Th2 lymphocyte ratio, modification of the profile of released cytokines, and induction of regulatory $\mathrm{T}$ cells. The therapy demonstrates a high efficacy in sclerotic lesions, mucosal involvement and fasciitis secondary to cGVHD $[7,8]$.

Another treatment modality for cGVHD is UVA1 phototherapy. The mode of action of the technique is ne oraz immunomodulujące. Ponadto wpływa na produkcję cytokin, aktywację komórek, prezentację antygenów i apoptozę, m.in. limfocytów T [10]. Skuteczność fototerapii stwierdzono zarówno w postaci ostrej, jak i przewlekłej GVHD. Metoda ta jest szczególnie dobrą alternatywą dla pacjentów z rozsianymi zmianami skórnymi, u których zastosowanie systemowej immunosupresji wiązałoby się z dużym ryzykiem rozwoju powikłań infekcyjnych lub innych działań niepożądanych.

W leczeniu pacjentów z cGVHD zastosowanie znajdują: UVB o szerokim spektrum (280-320 nm), UVB o wąskim spektrum (311 nm), PUVA (8-metoksypsoralen przyjmowany doustnie przed naświetlaniem UVA 320-400 nm) oraz UVA1 (340-400 nm). Przy wyborze metody fototerapii należy się kierować m.in. rodzajem zmian skórnych. W przypadku powierzchownych zmian, np. w postaci liszajopodobnej, wystarcza promieniowanie UVB, które jest absorbowane w naskórku i nie przenika do głębszych warstw skóry właściwej. Postać twardzinopodobna wymaga natomiast zastosowania promieniowania UVA ze względu na jego penetrację do skóry właściwej [7, 8]. Należy pamiętać, że stosowanie fototerapii zwiększa ryzyko rozwoju nowotworów skóry u biorców przeszczepów.

Ważną metodą leczenia pacjentów z cGVHD jest ECP. Fotofereza pozaustrojowa jest systemową fototerapią charakteryzującą się wysokim bezpieczeństwem. Składa się z trzech etapów: 1) wyizolowania leukocytów od pacjenta, 2) fotoaktywacji za pomocą związku fotouczulającego dodanego bezpośrednio do kożuszka leukocytarnego, a następnie naświetleniu leukocytów promieniowaniem UVA oraz 3) reinfuzji leukocytów. Cały zabieg trwa ok. 3-4 godzin. Najczęściej wykonywany jest przez 2 kolejne dni i powtarzany co 2-4 tygodnie [11, 12]. Po raz pierwszy ECP zastosowano w 1987 r. w leczeniu postaci erytrodermicznej pierwotnie skórnych chłoniaków T-komórkowych [13]. Obecnie metoda ta najczęściej wykorzystywana jest do leczenia cGVHD. Odsetek odpowiedzi u biorców przeszczepów wynosi ok. 63\% [11]. Do najczęstszych działań niepożądanych ECP należą: hipotensja w trakcie procedury, gorączka, rumień skóry i nudności [14]. Dokładny mechanizm działania w cGVHD nie jest poznany. Uważa się, że skuteczność wynika z wpływu na stosunek limfocytów Th1 do Th2, modyfikacji profilu wydzielanych cytokin i indukcji limfocytów T regulatorowych. Terapia cechuje się dużą skutecznością w przypadku zmian twardzinopodobnych, zajęcia błon śluzowych oraz zapalenia powięzi w przebiegu cGVHD [7, 8].

W leczeniu cGVHD stosuje się również fototerapię UVA1. Mechanizm jej działania opiera się na indukowaniu apoptozy limfocytów T tworzących nacieki w skórze oraz pobudzaniu wydzielania immunosupresyjnej interleukiny 10 przez keratynocyty. 
based on inducing apoptosis of T cells which form infiltrations in the skin, and stimulating the production of immunosuppressive interleukin 10 by keratinocytes. UVA1 also increases the activity of collagenase which might account for the particular efficacy of the treatment observed in the sclerotic form of CGVHD [7, 15]. The most common adverse effects of UVA1 phototherapy are erythema, pruritus, reactivation of the herpes virus, and emergence of polymorphous light eruptions. UVA1 is superior to PUVA in that it does not provoke nausea or prolonged photosensitivity, and eliminates the need for eye photoprotection [7].

Dermatological manifestations of cGVHD which often require a specific therapeutic management include poikilodermatous lesions, nail plate and scalp involvement, pruritus and non-healing ulcers.

1) Poikilodermatous lesions

Hyperpigmentation present in the inactive form of cGVHD can be treated with hydroquinone $4 \%$ cream either in monotherapy or in combination with topical GCs and tretinoin. The efficacy of the therapy is, however, limited [7, 8].

2) Involvement of skin appendages

Major psychological problems faced by patients include alopecia (both scarring and non-scarring types), premature greying, thinning and brittleness of hair as well as dystrophic nail lesions (longitudinal ridging, splitting, onycholysis, pterygium formation) or complete nail plate loss. Treatment is based on pharmaceuticals which are used in the therapy of nail lichen planus (due to a very similar pattern of inflammatory response underlying cGVHD) - potent steroid ointments, tazarotene, ointments containing a combination of betamethasone and calcipotriol. It should be noted, however, that both nail lesions and alopecia occurring in transplant patients are frequently refractory to treatment $[7,8]$.

\section{3) Pruritus}

A considerable improvement is normally achieved with systemic immunosuppressive therapy. However, adjuvant treatment should also be considered, including the elimination of factors which lead to skin drying, regular use of emollients, and avoidance of hot baths. Lotions are especially recommended in skin care due to their skin cooling effect. Dermal products containing polidocanol, menthol and camphor bring a substantial relief, too. An antipruritic effect can also be achieved with topical GCs and calcineurin inhibitors $[7,8]$. Another method, which is recommended for the treatment of pruritus in Western Europe, is the co-called wet wrap therapy. Immediately after the application of a cream or ointment, the skin is wrapped in a damp towel, and then with a dry towel, following which it is left for 1-2 hours [8]. Oral antihistamines, which are routinely used in the treatment of pruritus, usually demonstrate only
Promieniowanie UVA1 zwiększa również aktywność kolagenazy, co może tłumaczyć jego szczególną skuteczność w postaci twardzinopodobnej cGVHD [7, 15]. Do najczęstszych działań niepożądanych fototerapii UVA1 należą: rumień, świąd skóry, reaktywacja opryszczki, polimorficzne osutki świetlne. UVA1 przeważa nad PUVA, ponieważ nie wywołuje nudności ani przedłużonej nadwrażliwości na światło oraz nie wiąże się z koniecznością stosowania fotoprotekcji oczu [7].

Do objawów dermatologicznych w przebiegu cGVHD, wymagających często odrębnego podejścia terapeutycznego, należą: zmiany poikilodermiczne, zajęcie płytek paznokciowych i skóry owłosionej głowy, świąd oraz niegojące się owrzodzenia.

1) Zmiany poikilodermiczne

W nieaktywnej postaci cGVHD w terapii przebarwień można zastosować hydrochinon $4 \%$ krem w monoterapii lub w połączeniu z miejscowymi GKS i tretynoiną. Skuteczność tej terapii jest jednak ograniczona $[7,8]$.

2) Zajęcie przydatków

Dużym problemem psychologicznym dla pacjentów jest łysienie (zarówno bliznowaciejące, jak i niebliznowaciejące), przedwczesne siwienie, zmniejszenie gęstości włosów i ich łamliwość oraz zmiany dystroficzne paznokci (podłużne pobruzdowanie, rozdwajanie, onycholiza, powstanie skrzydlika) lub całkowita utrata płytek paznokciowych. W leczeniu stosuje się preparaty wykorzystywane w terapii liszaja płaskiego paznokci (ze względu na bardzo podobny wzorzec reakcji zapalnej leżący u podłoża cGVHD) - silne maści steroidowe, tazaroten, maści zawierające połączenie betametazonu z kalcypotriolem. Należy jednak pamiętać, że u pacjentów po przeszczepach zarówno zmiany paznokciowe, jak i łysienie są często oporne na leczenie [7, 8].

3) Świąd skóry

Znaczną poprawę przynosi na ogół systemowa terapia immunosupresyjna. Nie należy jednak zapominać o leczeniu wspomagającym, np. eliminacji czynników sprzyjających wysuszeniu skóry, regularnym stosowaniu emolientów, unikaniu gorących kąpieli. Do pielęgnacji skóry zaleca się zwłaszcza lotiony ze względu na ich działanie chłodzące. Preparaty zawierające polidokanol, mentol, kamforę przynoszą dużą ulgę. Działanie przeciwświądowe mają również miejscowo stosowane GKS i inhibitory kalcyneuryny [7, 8]. W krajach Europy Zachodniej w terapii świądu rekomenduje się też stosowanie tzw. mokrych opatrunków. Leczenie polega na owinięciu skóry wilgotnym ręcznikiem bezpośrednio po nałożeniu kremu lub maści, a następnie przykryciu całości suchym ręcznikiem i pozostawieniu na 1-2 godziny [8]. Doustne leki przeciwhistaminowe, zwykle stosowane w leczeniu świądu, wykazują na ogół niewielką skuteczność 
limited efficacy in cGVHD patients. A retrospective analysis of 67 patients has confirmed the efficacy of desloratadine used twice a day $(2 \times 10 \mathrm{mg})$ [16]. Other potentially beneficial medications include first-generation antihistamines with a sedative effect (e.g. hydroxyzine) and tricyclic antidepressants. It should be remembered, however, that drugs from these groups increase mucosal dryness. In refractory cases of pruritus, skin treatment can be supplemented with gabapentin at 300-400 $\mathrm{mg} /$ day [8].

4) Skin erosions and ulcers secondary to cGVHD (especially the sclerotic form)

Skin grafts can be used as a treatment for difficult-to-heal ulcers in patients with a treatment-refractory form of the disease. The first procedure of this type was performed in 1985, and the skin graft was harvested from the bone marrow donor [17]. The literature also contains reports of successful skin grafting both from HLA-identical relatives and unrelated donors $[7,18,19]$. Also, an endothelin-1 receptor antagonist (bosentan) and a phosphodiesterase- 5 inhibitor (sildenafil) have been shown to have efficacy in the management of severe digital ulcers developing in the sclerotic form of cGVHD due to disturbed perfusion [8]. Both drugs, however, are not approved for this indication. In cases of non-healing ulcers of atypical morphology, differential diagnostics should include vasculitis, skin cancers or cutaneous metastases arising from the primary disease.

\section{CONCLUSIONS}

Dermatologists play an important role in the care provided to transplant recipients. Post-allo-HSCT patients are at an increased risk of developing skin cancers, melanoma and dermal infections. In the patient discussed above, intensive skin involvement secondary to cGVHD was observed. Despite a successful bone marrow transplant the patient complained about a significantly reduced quality of life and difficulties in daily functioning. Dermatological management combining phototherapy with intensive topical treatment caused an improvement in the local condition of the skin, and helped to reduce joint contractures and pain during mobility. Consequently, the patient's well-being was shown to have improved. Comprehensive care provided to transplant patients should be based on ongoing cooperation between haematologists and dermatologists.

\section{CONFLICT OF INTEREST}

The authors declare no conflict of interest. u pacjentów z cGVHD. W retrospektywnej analizie 67 pacjentów stwierdzono skuteczność desloratadyny stosowanej dwa razy dziennie $(2 \times 10 \mathrm{mg})$ [16]. Pomocne mogą być leki przeciwhistaminowe I generacji o działaniu sedatywnym (np. hydroksyzyna) oraz trójpierścieniowe leki przeciwdepresyjne. Należy jednak pamiętać o nasileniu suchości błon śluzowych podczas stosowania leków z tych grup. W opornych przypadkach świądu skóry do leczenia można dołączyć gabapentynę w dawce 300-400 mg/dobę [8].

4) Nadżerki i owrzodzenia skóry w przebiegu cGVHD, zwłaszcza w postaci twardzinopodobnej

W przypadku trudno gojących się owrzodzeń $\mathrm{u}$ pacjentów z oporną na leczenie postacią choroby można zastosować przeszczepy skórne. Pierwszy tego typu zabieg przeprowadzono w 1985 r., a przeszczep skórny pochodził od dawcy szpiku [17]. Do tej pory opisano udane zabiegi przeszczepu skóry pochodzącej zarówno od krewnych HLA-identycznych, jak i niespokrewnionych dawców [7, 18, 19]. W leczeniu ciężkich owrzodzeń palców (rozwijających się w postaci twardzinopodobnej na skutek zaburzonej perfuzji) stwierdzono skuteczność antagonisty receptora dla endoteliny 1 (bosentan) oraz inhibitora fosfodiesterazy V (sildenafil) [8]. Oba leki nie są jednak zarejestrowane w tym wskazaniu. W przypadku niegojących się owrzodzeń o nietypowej morfologii w diagnostyce różnicowej należy uwzględnić zapalenie naczyń, nowotwory skóry lub przerzuty do skóry choroby podstawowej.

\section{WNIOSKI}

Dermatolodzy odgrywają ważną rolę w opiece nad biorcami przeszczepów. Pacjenci po allo-HSCT mają nie tylko zwiększone ryzyko rozwoju raków skóry, czerniaka oraz infekcji skórnych. U przedstawionego pacjenta doszło do nasilonego zajęcia skóry w przebiegu cGVHD. Pomimo udanego przeszczepu szpiku pacjent skarżył się na znacznie obniżoną jakość życia i utrudnienie codziennego funkcjonowania. Terapia dermatologiczna oparta na skojarzeniu fototerapii i intensywnego leczenia miejscowego spowodowała poprawę stanu miejscowego skóry, a także zmniejszenie przykurczów i bolesności w trakcie poruszania się, co przyczyniło się do poprawy samopoczucia pacjenta. Kompleksowa opieka nad pacjentami po przeszczepach powinna się opierać na stałej współpracy pomiędzy hematologami i dermatologami.

\section{KONFLIKT INTERESÓW}

Autorzy deklarują brak konfliktu interesów. 


\section{References}

\section{Piśmiennictwo}

1. Jagasia M., Arora M., Flowers M.E., Chao N.J., McCarthy P.L., Cutler C.S., et al.: Risk factors for acute GVHD and survival after hematopoietic cell transplantation. Blood 2012, 119, 296-307.

2. Jacobsohn D.A., Vogelsang G.B.: Acute graft versus host disease. Orphanet J Rare Dis 2007, 2, 35.

3. Filipovich A.H., Weisdorf D., Pavletic S., Socie G., Wingard J.R., Lee S.J., et al.: National Institutes of Health consensus development project on criteria for clinical trials in chronic graft-versus-host disease: I. Diagnosis and staging working group report. Biol Blood Marrow Transplant 2005, 11, 945-956.

4. Penas P.F., Fernandez-Herrera J., Garcia-Diez A.: Dermatologic treatment of cutaneous graft versus host disease. Am J Clin Dermatol 2004, 5, 403-416.

5. Skert C., Patriarca F., Speretto A., Cerno M., Fili C., Zaja F., et al.: Sclerodermatous chronic graft-versus-host disease after allogeneic hematopoietic stem cell transplantation: incidence, predictors and outcomes. Haematologica 2006, 91, 258-261.

6. Penas P.F., Jones-Caballero M., Aragues M., Fernandez-Herrera J., Fraga J., Garcia-Diez A.: Sclerodermatous graft-vs-host disease: clinical and pathological study of 17 patients. Arch Dermatol 2002, 138, 924-934.

7. Villarreal C.D., Alanis J.C., Perez J.C., Candiani J.O.: Cutaneous graft-versus-host disease after hematopoietic stem cell transplant - a review. An Bras Dermatol 2016, 91, 336-343.

8. Marks C., Stadler M., Hausermann P., Wolff D., Buchholz S., Stary G., et al.: German-Austrian-Swiss Consensus Conference on clinical practice in chronic graft-versus-host disease (GVHD): guidance for supportive therapy of chronic cutaneous and musculoskeletal GVHD. Br J Dermatol 2011, 165, 18-29.

9. Curtis R.E., Rowlings P.A., Deeg H.J., Shroner D.A., Socie G., Travis L.B., et al.: Solid cancers after bone marrow transplantation. N Engl J Med 1997, 336, 897-904.

10. Greinix H.T., Socie G., Bacigalupo A., Holler E., Edinger M.G., Apperley J.F., et al.: Assessing the potential role of photopheresis in hematopoietic stem cell transplant. Bone Marrow Transplant 2006, 38, 265-273.

11. Scarisbrick J.J., Taylor P., Holtick U., Makar Y., Douglas K., Berlin G., et al.: U.K. consensus statement on the use of extracorporeal photopheresis for treatment of cutaneous T-cell lymphoma and chronic graft-versus-host disease. Br J Dermatol 2008, 158, 659-678.

12. Scarisbrick J.: Extracorporeal photopheresis: what is it and when should it be used? Clin Exp Dermatol 2009, 34, 757-760.

13. Edelson R.L., Berger C., Gasparro F., Jegasothy B., Heald P., Wintroub B., et al.: Treatment of cutaneous T-cell lymphoma by extracorporeal photochemotherapy. Preliminary results. N Engl J Med 1987, 316, 297-303.

14. Apisarnthanarax N., Donato M., Korbling M., Couriel D., Gajewski J., Giralt S., et al.: Extracorporeal photopheresis therapy in the management of steroid-refractory or steroid-dependent cutaneous chronic graft-versus-host disease after allogeneic stem cell transplantation: feasibility and results. Bone Marrow Transplant 2003, 31, 459-465.

15. Petersen M.J., Hansen C., Craig S.: Ultraviolet A irradiation stimulates collagenase production in cultured human fibroblasts J Invest Dermatol 1992, 99, 440-444.

16. Schulz S., Metz M., Siepmann D., Luger T.A., Maurer M., Stander S.: Antipruritic efficacy of a high-dose antihistamine therapy. Results of a retrospectively analysed case series. Hautarzt 2009, 60, 564-568.

17. Knobler H.Y., Sagher U., Peled I.J., Wexler M.R., Steiner D., Rubinstein N., et al.: Tolerance to donor-type skin in the recipient of a bone marrow allograft. Treatment of skin ulcers in chronic graft-versus-host disease with skin grafts from the bone marrow donor. Transplantation 1985, 40, 223-225.

18. Ammer J., Prantl L., Holler B., Landfried K., Wolff D., Karrer S., et al.: Successful treatment of a refractory skin ulcer in chronic cutaneous GvHD after allogeneic HSCT with split-thickness skin allografting from the stem cell donor. Bone Marrow Transplant 2012, 47, 1368-1369.

19. Crocchiolo R., Nicolini F.E., Sobh M., Ducastelle-Leprete S., Labussiere H., Dubois V., et al.: Treatment of a severe extensive cutaneous chronic GVHD after allo-HSCT using glycerolyzed skin allografts and cultured epidermis from the same donor. Bone Marrow Transplant 2011, 46, 1153-1155.

Received: 2.11 .2016

Accepted: 3.03 .2017

Otrzymano: 2.11.2016 r.

Zaakceptowano: 3.03.2017 r.

How to cite this article

Żychowska M., Gruber-Kopczyńska J., Tupikowska-Marzec M., Maj J.: Chronic graft-versus-host disease - the role of dermatological treatment. Dermatol Rev/Przegl Dermatol 2017, 104, 112-121. DOI: https:/ doi.org/10.5114/dr.2017.67385 